\title{
Efficacy of Gamification to increase the Scientific Concepts Acquisition in science learning and creative problem solving skills for Second Preparatory Grade Students
}

\author{
Prepared by: Dr. Amany Mohamed Abd Elhamed Abuzied"
}

\begin{abstract}
:
This study reports on preparatory- stage students in Egyptian language school with a focus on Gamification and Creative problem solving (CPS). The research problem stated in "The shortage of acquiring the scientific concepts in science and retain it, in addition to weakness of creative problem-solving skills for 2nd prep Students". An oriented module prepared according to gamification principals and CPS skills and introduced in the summer semester of 2018 academic year to 25 candidates students in one of the language schools. They studied for 16 sessions, 2 sessions per week. Throughout the module, students studied through flipped classroom to promote their scientific concepts acquisition that encourage their meaningful understanding of the "Cell module" concepts and develop their creative problem solving skills through the challenges they faced in studding its lessons. To achieve the aim of the research, two learning instruments were built; "The cell module" student's booklet and teacher guide, in addition to the gamified cell sites through virtual learning environment. The framework that guided this study based on experiential, constructivist methods; their responses' data analyzed quantitatively and discussed qualitatively. The author developed two quantitative instruments: A Scientific concepts test and Creative problem solving questionnaire. The former was to probe the cognitive of the students had in relation to the scientific concepts of the cell module before and after their studies of the educational module. The second instrument used to measure the impact of the oriented module on promoting the students' skills in solving the scientific problems creatively. Statistical data analysis using Statistical Package for the Social Sciences indicates that students in their post-results had developed better cognitive organization for the scientific concepts of the cell module; positive responses towards solving the scientific concepts. Gamification has a motivational affordances and psychological outcomes (as well as behavioral, mental and cognitive ${ }^{\text {outcomes }}$.
\end{abstract}

Keywords: Gamification, Scientific concepts, Creative Problem Solving skills (CPS).

* Amany Mohamed Abdel Hamied Abuzied- Lecturer at faculty of EducationAin Shams University 


\section{مستخلص:}

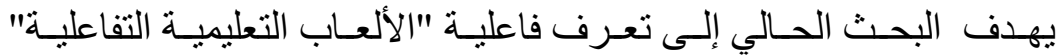
Gamification بطرق ابتكاريـة لطـلاب الصف الثاني الإعدادي بأحد مدارس اللغـات في مصـر .

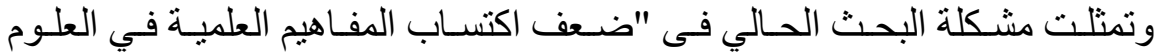

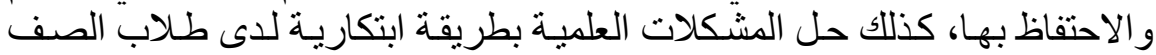

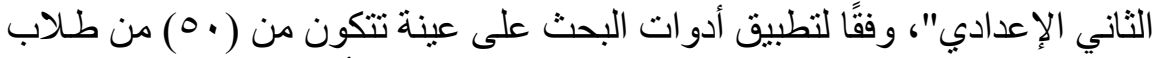

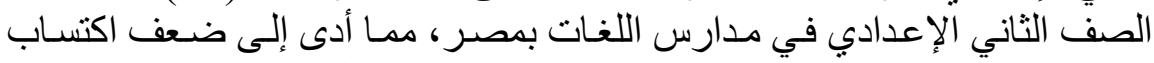

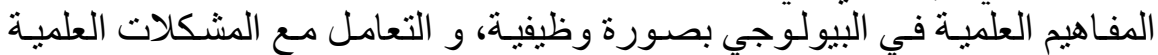
بحلول إبداعية. وللتغلب على هذه المشكلة تم بناء موديول "الخلية" ومفاهيمها القائم

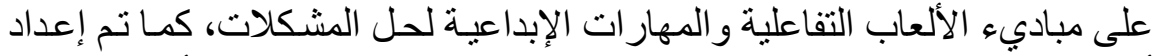

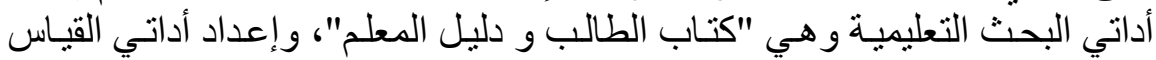
و همـا ( ـاختبـار المفـاهيم العلميـة: لقيـاس مدى إلمـام الطـلاب بمفـاهيم الخليـة قبـل

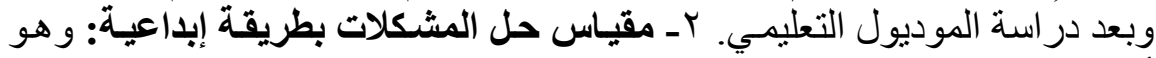

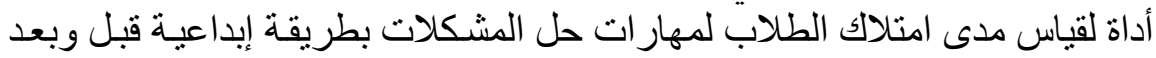

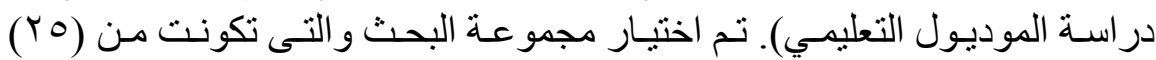

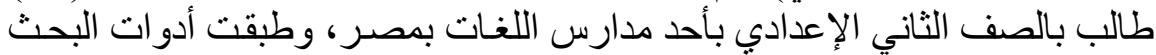

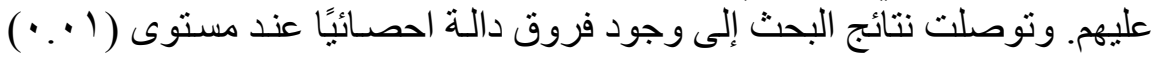
بين متوسطى درجات الطلاب فى التطبيقين القبلى و البعدى لكل من اختبـار المفـاهيم

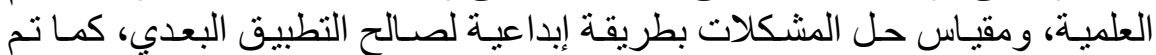

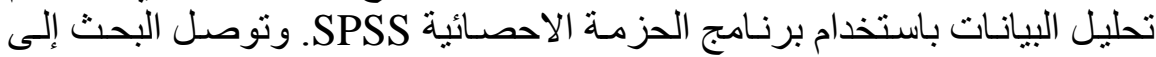

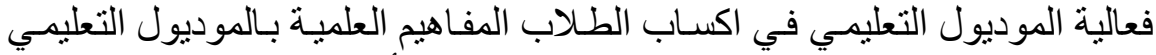

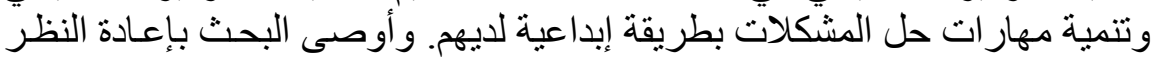

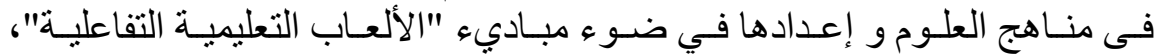

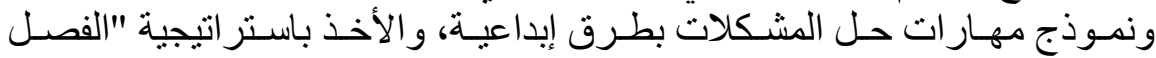

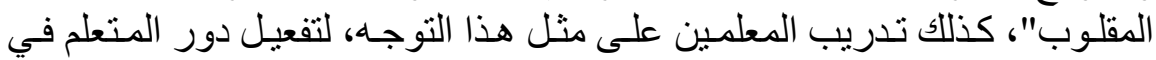
العملية التعليمية والانتقال من التعلم القائم على المعلم إلى التعلم القائم على الطالب.

الكلمات المفتاحية:

الألعاب التعليمية التفاعلية، اكتساب المفاهيم العلمية، المهارات الإبداعية

لحل المشكلات 


\section{INTRODUCTION:}

Scientific concepts considered one of the main components of scientific knowledge, its magic key and its basis. The educators emphasize the importance of scientific concepts acquisition in an accurate and correct method. In which this acquisition became main goal in all subjects over all curricula in every educational stages, and one of the important goals of scientific education.

Scientific concepts are fundamental to understand the general structure of science and knowledge. Moreover, it becomes the educational goal of science curricula for the learners to be able to proceed and follow the new in all sciences and knowledge disciplines. In addition, it becomes the foundation stone to learn the principals and the scientific theories (Zaytoon, 2003, p.84). Alnagdy, et al. (2003) assured that it is important to find the suitable methodology to introduce these concepts in a meaningful structure to the students to be able to acquire and retain it easily. Where scientific concepts in the science field are tools for reflection and inquiry, also it helps students to organize their experiences to think and solve the scientific problems (p.349).

The use of technology can help in increasing the learning engagement. Learning becomes a more active experience, stimulating students at a deeper level. Many education products employ the principles of gamification, which is the use of game mechanics in non-entertainment environments to change user behavior and drive engagement. The use of games to teach students is not new and the importance of play in facilitating learning has long been recognized. Today's technology provides for an even more immersive experience. Games increase enjoyment for students by providing rewards and feedback, which can improve students' attitudes toward learning traditionally challenging subjects like mathematics or science (Rubin, 2011, pp. 167-170).

Gamification approach increases participation and motivation of the learner, the learning process will be more effective, efficient, attractive and fun. Gamification has an active role in learning process; it enhances learning, student engagement and as a technological approach that is necessary and relevant to today's learner. Gamification can play a big role when we incorporate into the learning process by enhancing student engagement, learning and 
then student's motivation levels could be increased, so he could build his knowledge network. Besides, game applications give the sensation not being criticized or judged; activate a better memory by increasing levels of learning; stimulate creativity in problem solving accelerating the innovation processes; build a "customized knowledge" as mentioned by (Bozkurt, 2014).

The application of game design techniques and mechanics to problem solving has motivated students to overcome obstacles to reach desirable goals. The success of gamification in the corporate world has set a new standard for using strategic thinking to find creative solutions to the most baffling problems a student can face, including the discovery of new ways to overcome his real life challenges.

\section{Sense of the Problem:}

Our societies are dominated and even 'driven' by ideas and products from science and technology (S\&T), and it is very likely that the influence of science and technology on our lives will continue to increase in the years to come. Scientific and technological knowledge, skills and artefacts 'invade' all realms of life in modern society: the workplace and the public sphere are increasingly dependent on new as well as upon more established technologies, which reflected on our students' ways of thinking. In addition, this should be modified in our curricula to deal with these challenges especially in science learning, which become the foundation stone to understand many phenomena in our life. This should be oriented from the students' perspectives which interested in game- based learning full of challenges and this we called "student- centered learning". The researcher was confirmed from the previous by conducting pilot study on (50) random prep- stage students at many Egyptian language schools, through the application of the scientific concepts test and creative problem solving questionnaire prepared by the author in the second semester of the 2017/2018 academic year. The results of the pilot study were the shortage in scientific concepts and creative problem solving skills for preparatory grade students. This matched with many studies like (sung; chang \& Liu, 2016), (Elnemr, 2015), (Mahmoud, 2015), (Farahani; Hasan \& Noroozi, 2014), (UNESCO, 2010). 
Therefore, the researcher seeks to identify the effectiveness of Gamification in the development of scientific concepts acquisition and creative problem solving skills for Preparatory grade students, since to the researchers' knowledge, there is no Arab or foreign study done this research before.

\section{Statement of Problem:}

Although gamification is gaining more attention, there is a lack of studies, which would reveal its relations in fostering meaningful understanding to scientific concepts and solving the problems in a creative ways depending on the flipped learning trend. Most Preparatory students in Egypt schools face difficulties in science learning due to the complexity of this school subject especially in the way it taught by that lacks creating interest that is typical of conventional teaching methods. Gamification approach increases participation and motivation of the learner, the learning process will be more effective, efficient, attractive and fun" (Bozkurt, 2014). The author in the light of previous tried to deal with students' scientific concepts acquisition difficulties and their weakness of creative problem-solving skills by building an enrichment module "The Cell" through Gamification to deal with these difficulties especially in the language schools in which their students face difficulties also in the scientific concepts acquisition due to the foreign language. Therefore, the study seeks to answer the following research question: What is the efficacy of Gamification to increase the Scientific Concepts acquisition in science learning and enhancing the creatively problem solving skills for second prep. students? A number of sub-questions were raised to formulate the stages of the study:

1. What is the effectiveness of the suggested module to increase the students' scientific concepts acquisition?

2. What is the effectiveness of the suggested module to increase the students' creatively problem- solving skills?

\section{- The Study Objective}

\section{The study aims to:}

1. Build an oriented learning module according to gamification principals, supported with CPS model stages, which could help preparatory students in scientific concepts acquisition and 
enhance their creative problem solving skills.

2. Investigate if there are differences in the means of students' scores of scientific concepts test attributed to the oriented module.

3. Investigate if there are differences in the means of students' scores of problem solving questionnaire attributed to the oriented module.

4. Create a space to play, discuss, reflect on the challenges students faced during learning the module through flipped classroom, and create a positive learning environment to solve problems in an innovative way and acquire the cell module scientific concepts.

\section{- The Study Importance:}

The study is seeking to:

- Design an oriented module that could be used by teachers to employ Gamification and CPS model in teaching.

- Promoting teachers in helping their students to pleasantly acquire the scientific concepts, and develop their scientific concepts acquisition.

- Introduce a Scientific Concepts Test to the cell module, which could be used as an assessment tool in the cell topic.

- Introduce a CPS questionnaire that could be used by researchers in science-learning field.

\section{Methods:}

\section{- Research design:}

A mixed method was employed through descriptive analytical methods, which used to obtain information concerning the research problem situational variables, and carrying out analysis using quantitative and qualitative data. The experimental approach was mainly used in order to deal with the processes proposed at the different stages of the study that answer the research questions and address its main aims through the experimental group.

\section{- Profile of the participants:}

Convenience Sampling used to select participants of this study as they were enrolled in an oriented module, which needs 
students whom interested in science learning and educational technology, to be flexible to apply the oriented module objectives in one of the Egyptian language schools.

\section{- Terms and Procedural Definitions:}

1. Gamification: Gamification has been defined as "a process of enhancing services with (motivational) affordances in order to invoke gamely experiences and further behavioral outcomes in learning process" as expressed by Huotari\& Hamari (2012); Hamari (2013).

2. Acquisition of scientific concepts: It is the gaining of meanings and the scientific concepts in the cell module, and the ability to retain it easily, measured by the degrees obtained by students in the scientific concepts test prepared by the researcher for this purpose.

3. Creative problem- solving skills (CPS): They are skills that help students to redefine the problems and opportunities they face, come up with new, innovative responses and solutions, and then take action. The tools and techniques used make the process fun, engaging, and collaborative. CPS not only helps students create better solutions, it creates a positive experience that helps speed the adoption of new ideas through its stages' steps (Creative Education Foundation, 2015). They measured by the degrees that students gained in the CPS questionnaire prepared by the author.

\section{- Limitations of the research:}

1. Human limits: the study is limited to second prep. Stag Students, where a group of (25) students were enrolled in the study.

2. Place limits: the study was conducted in Hours language school associated the Ministry of Education in Egypt, Cairo governorate.

3. Time limits: the study was conducted during the summer term (August and September) of the academic year 2017/2018.

\section{- Procedures:}

Reoriented module based on Gamification principals to deal with the students' difficulties in scientific concepts acquisition in science through interesting student- centered learning approach. In 
addition, teaching methodologies that adopt gamification and preparing Teacher's guide introduces how to teach the module and Student book to the participants' students, also Gamification software and websites, which introduce the module concepts according to gamification principals. The main method in revising the research was by the "experimental" method. To make sure that the reoriented module followed an acceptable structure in terms of module design, learning objectives and description were then stated and reviewed from specialists in science education in Ain- Shams University. The module was a four-hour sessions per $\mathbf{8}$ weeks offered in the summer term in the academic year 2017/2018. The research tools applied pre and post the oriented module teaching, and quantitative data analyzed using Statistical Package for the Social Sciences (SPSS 9).

\section{- Review of Literature:}

The objective of this theoretical background review is to develop a vision for using Gamification in teaching and learning to develop the scientific concepts acquisition and creative problem solving skills. The theoretical framework includes the axes of the gamification, scientific concepts acquisition and creative problem solving skills (CPS).

\section{First: Gamification}

Over the past few years, there has been extensive discussion about the use of games in education. Gamification of education is a relatively new trend in education as mentioned by (Kapp, 2012), (Ferdig, 2009) \& (Salen and Zimmerman, 2004). Educators have long used games facilitated through other media to offer a useful framework for considering what constitutes a game. Based on gamerelated work from diverse disciplines including history, anthropology, sociology, philosophy, and education, these authors define a game as "a system in which players engage in an artificial conflict, defined by rules, which result in a quantifiable outcome". According to this framework, game systems define a boundary between an artificial game environment and the real world, and the artificial environment is partially defined by objects, attributes, rules, and a set of internal relationships. Games prescribe a conflict or contest that players negotiate through decision-making and actions. As players make progress toward the resolution of the 
conflict or contest, they earn points or other quantifiable markers denoting success (or failure). Games can be delivered through multiple media requiring varying levels of technology; in the current study, game mediated sites through computer-based virtual environment software were used.

Gamified content, especially often excel in creating an illusion of autonomy from a highly structured set of rules. Juul (2003) provides a more detailed definition of a gamified content, which is: "A gamified learning is a rule-based formal system with a variable and quantifiable outcome, where different outcomes are assigned different values, the player exerts effort in order to influence the outcome, the player feels attached to the outcome, and the consequences of the activity are optional and negotiable". Many of the elements listed in this definition are directly comparable to elements within formal learning, from 'variable and quantifiable outcomes' (grades) to the effort required by the learner ('player') to affect the outcome (gain a particular grade). A significant difference, however, is in the final clause, as the consequences of learning are typically more concrete and long lasting, for example failing within a formal learning process can have detrimental effects on the learner's future.

Some would say that gamification and game-based learning are the same. Others feel that they are different, and the difference is significant. Others say that they are slightly different but tend to overlap; the difference between the two concepts could be illustrated as follow. Gamification describes the process of applying game-related principles- particularly those relating to user experience and engagement- to non-game contexts such as education." These game-related elements include points, badges, leader boards, levels, stories, goals, social interaction, feedback, challenges, and these all introduced through strategies that depend on student-centered learning approach. Game-based learning, on the other hand, refers to the use of actual games to reach learning outcomes, while teaching/ learning strategies that used do not depend on student-centered learning approach (Nicolson, 2012).

Gamification is more about adding game elements to predetermined learning activities, lesson plans, and classroom practices, as a more first-person classroom exercise, whereas, game- 
based learning uses a comprehensive, interactive game, which is often more individual in nature, as the centerpiece around which students learn. The Gamification operates through experience systems based on a structured storytelling. The script of a game application include both game mechanics and dynamics: mechanics are the rules that make up the game settings and manage the interaction between player (input) and system (output); dynamics instead identify the behaviors adopted in game progression. The mind is so much pleasantly captured by the game setting, that it plunge into the "flow", a state of consciousness in which the user is totally immersed in a task: this state causes a total involvement, focus on the goal, positivity and gratification in performing a task.

Gamification has been defined as a process of enhancing services with (motivational) affordances in order to invoke gamely experiences and further behavioral outcomes as expressed by (Huotari \& Hamari, 2012) \& (Hamari, 2013). In defining gamification, they highlighted the role of gamification in invoking the same psychological experiences as games (generally) do. Deterding et al. (2011), on the other hand, emphasize that the affordances implemented in gamification have to be the same as the ones used in games, regardless of the outcomes. However, it is unclear which affordances are unique to games as well as which psychological outcomes can be strictly considered to stem from games. From the perspective of these definitions, there is room for a large variety of studies that could be framed as gamification. Therefore, one goal of this review is to explore what the actual empirical works on gamification have been studying as motivational affordances and psychological outcomes (as well as behavioral outcomes).

Just focusing on gamification for a moment, Hanus (2015) found that students who participated in gamified learning, in comparison with those who didn't, were more motivated, empowered, and satisfied with their learning, and that is positively affected their final grades. Interestingly, that study also suggested that a strong focus on rewards, as it is an extrinsic motivator, might be behind gamification's ineffectiveness. Therefore, as was stated in that study, "some care should be taken when applying certain gamification mechanics to educational settings." While in liu \& Chen (2013) study, which looked the effect of an educational card 
game on learning in science-related concepts, it reported positive results in terms of knowledge acquisition and developing positive attitudes towards learning.

Gamification in science education couldn't achieve the curriculum outcomes without many other factors like: a) the teacher awareness of this technique and its impacts on his students. b) The well-designed curriculum based on these virtual games. c) The restrictions or flexibility of the schools, d) the other technological aids such as virtual classroom. IT experts, educational software, internet availability, and e) assessing the students step by step after each activity to detect their needs as cited by (Becker, 2007, pp. 478-488) \& (Klopfer et al., 2009).

Briefly, success seems to be dependent on how gamification is implemented. "The effects are greatly dependent on the context in which the gamification is being implemented, as well as on the users using it," Glover (2013) cautioned, "to encourage meaningful learning experiences requires considerable thought about what is appropriate for the learners and the context. This is essentially the same as designing learning activities more generally, and gamification should be considered during this same design stage." (p.2005).

Glover (2013) stated, "Gamification has enhanced education technology in both the workplace and educational settings. Emerging technologies promise the availability of new tools that will make the virtual experience more practical and beneficial to existing and up-and-coming workforces. Gamification surpasses many alternative problem-solving tools because it continues delivering benefits long after helping to find solutions to a problem. The problem-solving skills developed through gamification will build a resilient organizational culture that routinely meets and overcomes challenges on the road to success." (p. 2000)

However, Virtual Learning Environments (VLEs) and Learning Management Systems (LMSes) make an ideal location for the implementation of gamification. This is because they typically contain all of the functionality required to support activities, resource sharing, and collaboration, as well as providing methods to track a learner's progress and interactions. In some systems, manual analysis of this data might be necessary; however, the recent interest 
in personalized learning has resulted in most of the major platforms implementing features that can be harnessed to gamify learning like Moodle, Blackboard and Edmodo. This could be further enhanced by making use of other features, such as using quizzes to assess the students' learning, or requiring a vote in a poll prior to moving to the next level (set of resources). When the learner has completed enough activities, or demonstrated a specific competency, a badge could be awarded automatically and displayed on their profile. Because of this perspective, the author presented the concept of gamification as enrichment elements in the oriented module to increase the students' scientific concept acquisition, and encouraging e-learning playing at home by accessing the module and games online through Edmodo virtual classroom. This could be supported with numerous classroom activities including laboratory exercises, brief lectures, formative assessments, small group activities, and whole-class discussions (Glover, 2013).

Research on educational games has documented the successful use of computer-based games like gamification for supporting a variety of learning outcomes important for science education. These outcomes include understandings of content in Clark et al. (2011) study, interest in science in Kuo (2007) study, inquiry skills in Ketelhut, Nelson, Clarke, \& Dede (2010) study, creativity such in Annetta, Cheng, \& Holmes (2010), scientific habits of mind in Steinkuehler \& Duncan (2008), and critical thinking in Squire (2006) study. A recent report from the National Research Council (NRC) on games and education concludes that: "Simulation and games have potential to advance multiple science learning goals, including motivation to learn science, conceptual understanding, science process skills, understanding of the nature of science, scientific discourse and argumentation, and identification with science and science learning (Honey \& Hilton, 2011, p. 54).

Given the sum of these findings, this research is interested in moving beyond the question of whether gamification support learning to how gamification can be used productively in science learning outcomes especially "the scientific concepts acquisition and Creative problems-solving skills". Gamified learning materials implemented through virtual classrooms to help students to achieve the curriculum outcomes in parallel with the in-classroom activities. This depends on the adolescents properties, which need this type of 
learning according to their age- stage as recommended by (Software Association, 2013).

\section{Second: Scientific concepts acquisition:}

Science is a great enterprise that nations depend on, in-order to advance technologically. Science therefore, is receiving much emphasis in education because of its significance and relevance to life and society. Science is the prerequisite subject for many fields of learning contributes immensely to the technological growth of the nation. This includes medicine, forestry, agriculture, biotechnology and nursing. The study of science concepts can equip students with useful concepts, principles and theories that will enable them face the challenges before and after graduation.

It has been observed that one common problem encountered by the students in the science learning is difficulty in understanding and acquiring scientific concepts. Many students become discouraged by the course because of the complex vocabulary they need (or they believe they need) to memorize in order to understand the subject. In effect, efforts should be made to reduce the total amount of information students are expected to memorize; reduce the use of the passive lecture format; and devote more effort to helping students become active, independent learners and problem solvers (Michel \& chen, 2006).

Science teachers and researchers have a vision that all students are capable of learning Science, This is done best in socially organized environments, and with a curriculum that is more studentcentered than teacher-centered as proved in (Hassard \& Dias, 2009). Scientific concepts are the axes around which science curriculum revolves. Zaytoon (2013) indicates that scientific concepts are considered basis of science and scientific knowledge that assist in understanding the structure of science transferring, the impact of learning, and connecting scientific facts. According to Murphy (2002), concepts are mental representations that allow us to draw appropriate inferences about the type of entities we encounter in our everyday lives. Concepts help us to make deductions and explain even more ideas that are complex.

Concepts can thus act as building blocks of more complex or even abstract representations as mentioned in (Zirbel, 2006, p.1221). Despite the significance of the scientific concepts, students face 
difficulties in acquiring these concepts such as lacking the scientific background as well as confusing between the scientific term with its meaning or verbal reference. One of these difficulties is represented in implementing traditional science learning as cited in (Khataybeh, 2011). Al-Tarawneh, M. (2016) indicated that, traditional science learning has been criticized for not engaging learners or fostering deeper understanding. The above mentioned difficulties can be overcome by using entertainment and fun-based teaching methods in which the learner acquires direct experience from his/ her active interaction in the learning process and the Educational games (gamification) can be considered as an example of these fun-based teaching methods (p.31).

A feature of most digital games is their combination of multiple sensory elements. They can be bright, colorful and often animated. Most have sounds, voices and/or music and require the player's physical interaction through keyboard or touchscreen actions. These visual, auditory and tactile elements activate multiple brain regions and thousands of neural circuits to process information and respond positively to acquire concepts. More activation that is neural means more mental stimulation, more engagement and ultimately, more learning.

Jean Piaget once wrote, "Play is the answer to the question: how does anything new come about?" When we provide opportunities for-and allow time for-students' self-initiated play, we are ensuring the full development of their curiosity, imagination, and creativity (Elkind, 2008). According to Salen \& Zimmerman (2004) a game is a system in which players engage in an artificial conflict, defined by rules, that results in a quantifiable outcome. Kirriemuir \& McFarlane (2004) reported implementation of games elements in education is a powerful learning tool, adding fun, and increase the scientific concepts acquisition.

Acquisition of scientific concepts normally occurs through the learners' interaction with the stimulations faced and experiences went through. This assisted learners in shaping a mental image of these stimulations and experiences based on the common characteristics of the stimulations. Educational games through gamified learning content increase self-confidence to students as 
they reinforce the active role of the students in the learning process by participating in gaining knowledge. Al-Tarawneh (2016) \& Folta (2010) showed that students not only enjoyed playing the game, but felt that it was a good educational tool because the outdoor science educational games made them felt they learned how to identify tracks of biological concepts depending on the role they play.

It is well known that certain concepts related to biology are generally perceived by students to be abstract, complex and difficult. This situation may cause students to get bored. Gamification, increases motivation by converting boring and difficult tasks into entertaining and achievable ones. This could be done through an effective student- centered learning approach. Researchers' state that intrinsic motivation can be increased via a well-organized gamification process and that students can eventually spend more time on course-related materials (Muntean, 2011) \& (Nicholson, 2012).

Yapici \& karakoyun (2017) examined whether science teachers would use gamification site in their future classes or not after involving them in his experimental study, they argued that they certainly would use it because it enhanced students' participation in their classrooms. Gamification had positive effects on active participation as well as on attendance in class and that, the students found the gamification process more pleasing, motivating and interesting when compared to the traditional teaching process.

In addition, Klisch, Miller, Wang and Epstein (2012) found that science education gamification was effective in increasing adolescents' knowledge about the science content presented in the game. Furthermore, the increased knowledge resulted in a shift toward more negative attitudes in inhalants, indicating that the game was successful in enabling adolescents to identify inhalants as body pollutants. Furthermore, the results of research by Liu and Chen (2013) indicated that students demonstrated positive attitudes toward the use of the educational card game in science learning, and demonstrated the effectiveness of the proposed education card game in improving students' scientific knowledge of transport and energy. 


\section{Third: Creative problem- Solving Skills (CPS):}

In the fast-changing world that we live in today, education must adapt to the different circumstances and technological trends. The reason is simple; the only way to survive the constant flow of ambiguity that change provides is by learning to be flexible and to communicate in different ways. However, in order to be able to prepare students to embrace change, the learning needs to be designed in a holistic way that addresses both cognitive and emotional ways of thinking.

When students play games, they feel a sense of purpose and experience a desire for accomplishment. Every time players reach a new level of the game, they feel proud and then eagerly embark on the next challenge. Such a universal human experience now plays a significant role in the education world. Subjects with stagnant problem-solving skills and a lack of responsiveness to changes in their environment discovered they could reinvigorate their organizations by converting the problem solving into a game by setting goals and engaging students in a competition now called gamification (Sanchez, 2011).

Gamification has enhanced education technology in both the workplace and educational settings. Emerging technologies promise the availability of new tools that will make the virtual experience more practical and beneficial to existing and up-and-coming workforces. Gamification surpasses many alternative problemsolving tools because it continues delivering benefits long after helping to find solutions to a problem. The problem-solving skills developed through gamification will build a resilient organizational culture that routinely meets and overcomes challenges on the road to success (Ferguson, 2011).

Using gamification to aid in cognitive development will allow an increase in the activity of the regions of the brain to allow for adequate development. Games that are produced specifically for enhancing cognitive development are often referred to as "brain games" Brain games have become increasingly popular and it depends on various questions and problems that the user has to answer or solve. Brain games can improve the rate in which the brain processes and maintains information (Twining, 2010). 
The teaching of CPS through gamified content is very approachable and helps to reinforce the fact that the teaching of CPS is life changing. It not only allows students to find creative resolution to their problems, but also changes their attitude when the process is practiced repeatedly. "They seem to become more open to ideas; they also seem to appreciate and have a greater deal of respect for their own knowledge". It also encourages creativity because of the interaction between thinking and emotion (Puccio, Mance \& Murdock, 2011, p.82).

CPS is a proven method for approaching a problem or a challenge in an imaginative and innovative way. It helps students redefine the problems and opportunities they face, come up with new, innovative responses and solutions, and then take action. The tools and techniques used make the process fun, engaging, and collaborative and this could be done through gamification steps. CPS not only helps create better solutions, it creates a positive experience that helps speed the adoption of new ideas. (Creative Education Foundation, 2015) described CPS as the sum of its parts: a) Creative: specifies elements of newness, innovation, and novelty;

b) Problem refers to any situation that presents a challenge, offers an opportunity, or represents a troubling concern; c) Solving: means devising ways to answer, to meet, or to satisfy a situation by changing self or situation.

\section{(Creative Education Foundation, 2015) detected the Core Principles of Creative Problem Solving in:}

- Divergent and convergent thinking must be balanced: Keys to creativity are learning ways to identify and balance expanding and contracting thinking (done separately) and knowing when to practice them. This matched with gamification through its flipped classroom approach.

- Ask problems as questions: Solutions are more readily invited and developed when challenges and problems are restated as openended questions with multiple possibilities. Such questions generate lots of rich information, while closed-ended questions tend to elicit confirmation or denial. Statements tend to generate limited or no response at all. This could be done through involving the students in the gamified challenges and supporting the learning process with such type of questions. 
- Defer or suspend judgment: As Osborn learned in his early work on brainstorming, the instantaneous judgment in response to an idea shuts down idea generation. There is an appropriate and necessary time to apply judgment when converging. This could be done during the transferring from one level to the other in the gamified challenges.

- Focus on "Yes and ..." rather than "No, but..." When generating information and ideas, language matters. "Yes, and" allows continuation and expansion, which is necessary in certain stages of CPS. The use of the word "but"-whether preceded by "yes" or "no"- closes down conversation, negating and everything that has come before it. This fluency in ideas could immerge during collaboration in the group working gamification activities.

CPS Model: In the most recent iteration of the CPS Model, Uribe \& Cabra (2010) detected four stages with six explicit steps. Within each stage, each step uses divergent and convergent thinking to measure the creativity of problem solving as follow:

Table (1) CPS model stages

\begin{tabular}{|c|l|l|}
\hline Stage & \multicolumn{1}{|c|}{ Step } & \multicolumn{1}{c|}{ Purpose } \\
\hline CLARIFY & $\begin{array}{l}\text { 1. Explore the Vision } \\
\text { 2. Gather Data } \\
\text { 3. Formulate the } \\
\text { challenge }\end{array}$ & $\begin{array}{l}\text { + Explore the Vision } \\
\text { Identify the goal, wish, or } \\
\text { challenge. } \\
\text { Gather Data, Describe and } \\
\text { generate data to enable a } \\
\text { clear understanding of the } \\
\text { challenge. } \\
\text { Formulate the Sharpen } \\
\text { awareness of the challenge } \\
\text { and create Challenge } \\
\text { questions that invite } \\
\text { solutions. }\end{array}$ \\
\hline IDEATE & 4. IDEATE ideas & $\begin{array}{l}\text { Generate ideas that answer the } \\
\text { challenge questions. }\end{array}$ \\
\hline DEVELOP & 5. Formulate Solutions & $\begin{array}{l}\text { To move from ideas to solutions, } \\
\text { Evaluate, strengthen, and select } \\
\text { solutions for best "fit." }\end{array}$ \\
\hline IMPLEMENT & 6. Formulate a Plan & $\begin{array}{l}\text { Explore acceptance and identify } \\
\text { resources and actions that will } \\
\text { support implementation of the } \\
\text { selected solution(s). }\end{array}$ \\
\hline
\end{tabular}


This model and its stages could be merged with gamification principals through the teaching process, which depends on challenges and problem to be solved. There are many studies, which studied the effect of some methods or strategies on developing the students' creative problem solving like: Brainstorming as detected by Al-khatib (2012), Educational Program based on problem solving model as proved by Al-abadi, Z. (2008), Trafnger model as illustrated by Al-lala, S. (2009). However, there is no studies searched the impact of gamification on enhancing the creative problem solving to the preparatory stage students according to the knowledge of the researcher.

Based on the views discussed above on the benefits of gamification and based on the assumption that teaching and learning Science is more acceptable -for adolescents students- if tangible objects were employed to acquire scientific concepts, the present study investigates the effectiveness of gamification on acquiring scientific concepts and creative problem solving skills to the $2^{\text {nd }}$ prep. stage students. The researcher benefited from reviewing the theoretical framework in preparing the research tools.

\section{- Research Hypotheses:}

To solve the research problem and answer the research questions, the researcher tested the following hypotheses:

1. There is a statistically significant difference between the mean score of the pre and post- administration of the scientific concepts test in fever of the post administration.

2. There is a statistically significant difference between the mean score of the pre and post- administration of CPS questionnaire in fever of the post administration.

\section{- Methodology:}

To answer the questions of the study and check the validity of its hypothesis, the following procedures were followed:

\section{First: Preparing the Learning materials:}

1- Selecting the scientific content: the researcher selected "the cell" topic to be learning module content because it is full of large scientific content, which is taught to the students in primary and preparatory stages at many levels of difficulties. In addition, 
it contains a lot of scientific concepts that confuse most of students, according to the science teachers and students' complaints that the research recorded from many preparatory science teachers and students. The cell is a unit in their governmental science curriculum, which represent a scientific basis for the following years. The teaching time of the cell module is relatively large according the nature of gamification principals, and due to its large scientific content and the varieties of challenges and mental activities, illustrated in details in the teacher guide appendix (2).

\section{2- Preparation of the cell module student's booklet through the following:}

a) Identify the aim of the module, and its lessons' learning objectives, specification table for teaching the module, which is 16 sessions, 2 sessions per week including the application of the measuring instruments, in addition to 7 hours homework.

b) Construct the virtual classroom through Edmodo platform to communicate with the students, upload the content material interval on it, and send its code to the students.

c) Preparation of the student's booklet based on the module objectives: the researcher formulated the procedural objectives according to the Gamification principals steps which are (assessing the students- defining learning goals- structuring the gamifying experiences- identifying principals- applying gamification elements). This illustrated in details in the teacher guide (appendix 2), and support the module with the creative problem solving principals to develop its skills to the participants. The module content checked by some experts in science curricula at Ain- Shams University to establish its appropriateness for achieving the desired aims of the current research, suitability of the educational activities, evaluation techniques and the language used. Computation factor for content analysis validity was calculated with "Scott coefficient" through the following equation:

$$
\pi=\frac{\operatorname{Pr}(a)-\operatorname{Pr}(e)}{1-\operatorname{Pr}(e)},
$$


The coefficient was 0.9 , which is acceptable, and reflects the reliability of the module content and the internal consistency of its content. The researcher modified the student's guide as directed by jury until the guide appeared in its final shape (appendix 2).

d) Knowledge Construction activities: Students responded to the flipped classroom instructions, and checked the contents before their sessions on gamification sites uploaded to them, and investigate the scientific concepts during the social interaction with their groups and colleges. They practiced the creative problem solving subconsciously through dealing with the gamified cell virtual environment in class and during their home- working hours, following the teacher's instructions. Students reflected on their work in each lesson, discriminate between their in class and virtual classroom activities in knowledge acquiring and giving conclusion.

\section{3- Preparation of the cell module teacher's guide through the following:}

The researcher prepared the guide according to the following steps:

a) Illustrating the aim of the module, and the objectives of its lessons.

b) Developing a brief theoretical framework on: "Gamification, its principals, How to gamify your class, gamification and its relation to scientific concepts acquisition, gamification and its relation to creative problem- solving".

c) Illustrating the general information of the module, which are: (1-Its name: "The cell module", 2-the required hours: About 21 Hours divided between Class and home hours as follow:14 hours in 16 session, 2 sessions per week (each session 45 minutes) and 7 home- working hours ( 2 hours weekly), 3-The prerequisites and the module's content which is: "The cell history and definition, organelles names and function, adaptations, and flow of substances from and out of cell and Cell Division").

d) Detecting the module's activities: and how to apply before and during each lesson.

e) Detecting the learning sources: which are (Student's 
booklet, Gamified- learning websites, Internet for enrichment information, Enrichment gamified sites for further information and the teacher's perspective for creativity).

f) Methodology: There is mix of strategies and methods that used to implement the module goals. Each one illustrated clearly in details and how to apply during the module' procedures in the teacher guide (Appendix 2), and they are: (Gamification- Active lecture method- Discussion methodAnalogies strategy- "pop sickles" method- Storytelling method- Flipped classroom strategy- Analogies- "Think- PairShare" strategy-"Commit and Toss" method- "Watch- Think and Dig deep" strategy).

g) Assessment and Evaluation: Students assessed through some activities and evaluated through (activities in class, Quizzes, class discussions, challenges overcome in the gamified sites, Reflection, Applying the post- measure instruments). The researcher illustrated in details the instructions of applying the assessment tools, and how to give feedbacks to the students to formulate their thinking ways process in the teacher guide (Appendix 2).

h) Illustrating the module lessons plan: Give a time plan to how to teach each lesson and its class and home-working hours.

Second: Preparation of the assessment instruments of the research: To identify the efficacy of "Gamification" in developing the scientific concept acquisition and the creative problem solving skills for the second preparatory students, two instruments were prepared which are scientific concepts test and creative problem solving questionnaire. The following procedures were followed:

1- Preparation of the scientific concepts test: the test was prepared as follow:

a) Identifying the aim of the test: This test is prepared to measure the ability of the students to acquire the scientific concepts and retain them after studding the cell module.

b) Analyzing the module content: The referees detected the relative weight to each module's subjects, researcher considered it and then analyzed the cell module content to 
extract the scientific concepts in each lesson to detect the specification table of the test and the weight of concepts in the test according to its weight in each lesson as shown below:

Relative weight to each subject importance=n. of each subject session / total $n$. of all session $\times 100$

Table (2) Relative weight of cell module subjects

\begin{tabular}{|c|c|c|c|c|c|c|c|c|c|c|c|}
\hline $\begin{array}{c}\text { Module } \\
\text { content }\end{array}$ & $\begin{array}{c}\text { Sub. } \\
\mathbf{1}\end{array}$ & $\begin{array}{c}\text { Sub } \\
\mathbf{. 2}\end{array}$ & $\begin{array}{c}\text { Sub. } \\
\mathbf{3}\end{array}$ & $\begin{array}{c}\text { Sub. } \\
\mathbf{4}\end{array}$ & $\begin{array}{c}\text { Sub. } \\
\mathbf{5}\end{array}$ & $\begin{array}{c}\text { Sub. } \\
\mathbf{6}\end{array}$ & $\begin{array}{c}\text { Sub. } \\
\mathbf{7}\end{array}$ & $\begin{array}{c}\text { Sub. } \\
\mathbf{8}\end{array}$ & $\begin{array}{c}\text { Sub. } \\
\mathbf{9}\end{array}$ & $\begin{array}{c}\text { Sub.1 } \\
\mathbf{0}\end{array}$ & Total \\
\hline $\begin{array}{c}\text { Sessions } \\
\text { number }\end{array}$ & 1 & 1 & 1 & 1 & 1 & 1 & 1 & 1 & 1 & 1 & 10 \\
\hline $\begin{array}{c}\text { Relative } \\
\text { weight }\end{array}$ & $10 \%$ & $10 \%$ & $10 \%$ & $10 \%$ & $10 \%$ & $10 \%$ & $10 \%$ & $10 \%$ & $10 \%$ & $10 \%$ & 100 \\
\hline
\end{tabular}

Table (3) Specification table of scientific concepts test

\begin{tabular}{|c|c|c|c|c|c|c|}
\hline \multirow[b]{2}{*}{$\begin{array}{l}\text { Lesson } \\
\text { number }\end{array}$} & \multirow[b]{2}{*}{$\begin{array}{l}\text { Number of } \\
\text { Academic } \\
\text { vocabulary }\end{array}$} & \multicolumn{2}{|c|}{ Cognitive domain levels } & \multirow{2}{*}{$\begin{array}{c}\text { Number } \\
\text { of items } \\
\text { of each } \\
\text { lesson in } \\
\text { the test }\end{array}$} & \multirow[b]{2}{*}{$\begin{array}{l}\text { Items' numbers in the } \\
\text { scientific concepts test }\end{array}$} & \multirow{2}{*}{$\begin{array}{c}\text { Percentage } \\
\% \text { of each } \\
\text { lesson } \\
\text { questions in } \\
\text { the test }\end{array}$} \\
\hline & & $\begin{array}{c}\text { Knowledge- } \\
\text { level } \\
\text { Questions }\end{array}$ & $\begin{array}{c}\text { Understanding } \\
\text { Level } \\
\text { Questions }\end{array}$ & & & \\
\hline 1 & 7 & $6,11,12,15$ & 8 & 5 & $6,8,11,12,15$ & 7.7 \\
\hline 2 & & & & & (Merged together & \\
\hline 3 & 22 & $\begin{array}{c}2,5,9,16,19 \\
22,23,25,28, \\
30,32,33,34 \\
36,38,39,42 \\
\quad 44,47\end{array}$ & 18,45 , & 22 & $\begin{array}{c}\text { because they are } \\
\text { related to each other) } \\
2,5,9,16,18,19,22, \\
23,25,28,30,32,33 \text {, } \\
34,36,38,39,42,44, \\
45,47\end{array}$ & 36.66 \\
\hline 4 & 12 & $\begin{array}{c}10,24,26,35 \\
37,48\end{array}$ & 14,41 & 8 & $\begin{array}{c}10,14,24,26,35,37, \\
41,48\end{array}$ & 13.2 \\
\hline 5 & 11 & $\begin{array}{c}3,21,46,51 \\
54,57\end{array}$ & 27,49 & 8 & $\begin{array}{c}3,21,27,46,49 \\
51,54,57\end{array}$ & 12.1 \\
\hline 6 & 6 & $4,50,60$ & 52, & 4 & $4,50,52,60$ & 6.5 \\
\hline 7 & 2 & 53, & & 1 & 53 & 2.2 \\
\hline 8 & 9 & $17,29,55,58$ & 43,56 & 6 & $17,29,43,55,56,58$ & 9.9 \\
\hline 9 & 5 & $1,7,40$ & & 3 & $1,7,40$ & 5.6 \\
\hline 10 & 5 & $13,20,31$ & & 3 & $13,20,31$ & 5.6 \\
\hline Total: 10 & 91 & & & 60 & & $100 \%$ \\
\hline
\end{tabular}

c) Formula of the test: The test was prepared in the MCQ formula, 60 items in the knowledge and high levels of understanding without the high levels of objectives, because it is a scientific concepts acquisition test not an achievement test, aimed to check the ability of students to acquire and keep those concepts. The items distributed to cover the concepts weights, which calculated through the specification table. 
d) Test validity: To check the test validity, it was submitted to a panel of jury to validate the comprehensiveness of the items, their suitability to the aim, preciseness of their formulation, their clarity and their language. The Spearman's rank-order correlation used to detect the consistency of the test by this equation: Reliability Coefficient $=\frac{2 r}{1+r}$ and it was 0.78 , which is efficient, and reflects the test internal consistency, modification was made and the test included 60 items.

e) Piloting the test: The test was administrated to a piloting group that consisted of $453^{\text {rd }}$ grade students at 2 language schools (Cairo international schools and Horus language schools), Cairo Governorate, whom finished studding the cell unit in the academic year 2016/2017 according to the traditional teaching methods to determine their acquirements to the cell scientific concepts. The ease and difficulty coefficient to each item calculated, the coefficients' of all test items ranged from (0.83- 0.16) which reflect the suitability of the test items. The reliability checked through the following:

Test reliability: Test reliability calculated by using Cronbach's Alpha formula statistically through SPSS package. Reliability coefficient was 0.75 , which is an acceptable and suitable one and indicates the reliability of the test for application.

The time needed for answering the test: This was calculated by estimating the average of the time taken by the students in the pilot study. The average was " 60 minutes" including reading the test instructions.

f) The final version of the test: In light of the previous results and procedures, the test putted in its final form consisted of 60 items (Appendix 4). Instructions were putted in the beginning of the test with one example and answer sheet were prepared.

g) The test correction: The test corrected, as 1 degree to each item, which has one correct answer, the maximum score of the test was 60 degrees, and the minimum score was zero. 
2- Preparation of the Creative Problem-Solving Questionnaire:

a) Identifying the aim of the questionnaire: This questionnaire is addressed to measure the student's creativity in problemsolving after their orientation in the cell module.

b) Identifying the dimensions of the measure: After reviewing literature and previous studies related to the creative problemSolving, the questionnaire is putted in two parts according to CPS model stages that has mentioned in the literature part; the first part is 17 (likert-scale) items with 5 responses (very often, often, sometimes, rarely, not at all). The second part is three problems with a MCQ \& essay (11) questions were addressed to measure the student's creativity in solving the scientific problems. The relative weight of the stages in the questionnaire putted according to the nature of the scientific problem in the questionnaire and its required CPS model steps.

c) Writing the instructions of the measure: The instructions of the questionnaire were written in a clear language, which makes it easy for students to understand and respond to its parts after introducing it to the pilot group to check its items clarity. It also included an illustrative example to guide the student.

h) Validity of the measure: To check the questionnaire validity, it was submitted to a panel of jury to validate the comprehensiveness of the items, their suitability to the aim, preciseness of their formulation, their clarity and their language, modification were made and the questionnaire included 2 parts as illustrated before.

d) Piloting the measure: The measure in its first form was administrated to the same scientific concepts test pilot group, in order to check:

Its reliability: it calculated by Cronbach's Alpha formula, which was 0.74 , so the measure is applicable.

Duration of the measure: The average time for all the students in the pilot study to finish responding was 45

minutes. 
e) Scoring the measure: The positive statements are given 5 degrees for its responses according to its nature depending on the CPS model 4 stages, which illustrated clearly in its model answer. The maximum score of the questionnaire is 110 degrees.

f) The final version of the CPS questionnaire: After making the modifications, the final version of the questionnaire prepared (Appendix 4). Specifications of the first and second part are presented in the following tables:

Table (4) Specification table of CPS questionnaire's first part

\begin{tabular}{|c|c|c|c|c|c|c|}
\hline $\mathrm{N}_{0}$. & Stage name & CPS 4 stages' step & $\begin{array}{c}\text { Positive } \\
\text { items }\end{array}$ & $\begin{array}{c}\begin{array}{c}\text { Negative } \\
\text { items }\end{array} \\
\end{array}$ & Total score & $\begin{array}{l}\text { Percentage } \\
\text { of each stage }\end{array}$ \\
\hline 1 & Implement stage & Plan & * & & 5 & \multirow{5}{*}{$\begin{array}{l}\text { 1- Clarify } \\
\text { stage } \\
35.23 \%\end{array}$} \\
\hline 2 & Implement stage & Share the Idea & * & & 5 & \\
\hline 3 & Clanify stage & Define the Problem & * & & 5 & \\
\hline 4 & Ideate Stage & Find Ideas & & * & 5 & \\
\hline 5 & Implement stage & Share the Idea & * & & 5 & \\
\hline 6 & Develop Stage & Select and Evaluate & * & & 5 & \multirow{4}{*}{$\begin{array}{c}\text { 2- Ideate } \\
\text { Stage } \\
11.76 \%\end{array}$} \\
\hline 7 & Clarify stage & Find the problem & & * & 5 & \\
\hline 8 & Implement stage & Share the Idea & & * & 5 & \\
\hline 9 & Clarify stage & Define the Problem & & * & 5 & \\
\hline 10 & Clanify stage & Find the Facts & * & & 5 & \multirow{3}{*}{$\begin{array}{c}\text { 3- Develop } \\
\text { Stage } \\
17.64 \%\end{array}$} \\
\hline 11 & Implement stage & Share the Idea & & * & 5 & \\
\hline 12 & Clarify stage & Find the problem & & * & 5 & \\
\hline 13 & Ideate Stage & Find Ideas & * & & 5 & \multirow{5}{*}{$\begin{array}{l}\text { 4- Implement } \\
\text { stage } \\
35.23 \%\end{array}$} \\
\hline 14 & Clarify stage & Find the Facts & & * & 5 & \\
\hline 15 & Develop Stage & Select and Evaluate & * & & 5 & \\
\hline 16 & Implement stage & Plan & & * & 5 & \\
\hline 17 & Develop Stage & Select and Evaluate & & * & 5 & \\
\hline \multicolumn{3}{|c|}{ Total } & 8 & 8 & 80 & $100 \%$ \\
\hline
\end{tabular}


Table (5) Specification table of CPS questionnaire's second part

\begin{tabular}{|c|c|c|c|c|}
\hline $\mathrm{N}_{0}$ & Stage name & CPS 4 stages' step & $\begin{array}{l}\text { Total } \\
\text { score }\end{array}$ & $\begin{array}{l}\text { Percentage of each } \\
\text { stage }\end{array}$ \\
\hline 1 & Clarify stage & Explain Phenomena scientifically & 2 & \multirow{11}{*}{$\begin{array}{c}\text { 1- Clarify stage } \\
23.53 \% \\
\text { 2- Ideate Stage } \\
29.41 \% \\
\text { 3- Develop Stage } \\
23.53 \%\end{array}$} \\
\hline 2 & Ideate and Develop & Evaluate and design scientific inquiry & 5 & \\
\hline 3 & Develop and Implement & Interpret data and evidence scientifically & 3 & \\
\hline 4 & Clarify and Ideate & Interpret data and evidence scientifically & 1 & \\
\hline 5 & Clarify and Ideate & Interpret data and evidence scientifically & 1 & \\
\hline 6 & Clarify and Ideate & Interpret data and evidence scientifically & 2 & \\
\hline 7 & Implemen & Evaluate and Design Scientific Enquiry & 3 & \\
\hline 8 & Implement stage & Evaluate and Design Scientific Enquiry & 3 & \\
\hline 9 & Ideate \& Develop & Explain phenomena scientifically & 4 & \\
\hline 10 & Develop stage & Interpret Data and Evidence Scientifically & 2 & \\
\hline 11 & Implement & $\begin{array}{l}\text { Implement solution by interpreting the } \\
\text { available data }\end{array}$ & 4 & \\
\hline & Total & & 30 & $100 \%$ \\
\hline
\end{tabular}

\section{Fourth: Field Application}

The field application has gone through the following stages:

1. Pre-using of the learning materials: the researcher met with the science teachers and the experimental group to clarify: "the purpose of the research, its importance and philosophy, how to use the teacher's guide, how to construct a virtual classroom on Edmodo platform, and how to train the students to use it".

2. Pre-administration of the assessment instruments: The instruments of the research (scientific concepts test and CPS questionnaire) were administrated to the experimental group before teaching the module on $15 / 8 / 2018$ to get data related to the pre- measurement. Teachers illustrated the significance of the CPS questionnaire to the students on their Edmodo class, and illustrated how they could enhance their skills with the helping of the CPS answer model guide (Appendix 4).

\section{Results of the study and their interpretations:}

This section presents results of the research in terms of its hypotheses as follow: 
First: Results of the administration of the scientific concepts test, and checking the validity of the first hypothesis:

To verify the validity of the first hypothesis, means and standard of deviations of the post score for the experimental group, SPSS 9 package was applied using the one- pair t- test to illustrate the $\mathrm{t}-$ value and its significance, the next table illustrated the results:

Table (6) Comparison of pre and post- test results for second prep. Stage students' Scientific Concepts Test items

\begin{tabular}{|c|c|c|c|c|c|c|c|c|c|c|c|c|c|c|c|}
\hline Question & measurement & $\mathrm{N}$ & Mean & $\begin{array}{c}\text { Std. } \\
\text { Deviation }\end{array}$ & $\mathrm{df}$ & \begin{tabular}{|c|}
$\mathrm{T}$ \\
value
\end{tabular} & Sig. & Question & Measurement & $\mathrm{N}$ & Mean & $\begin{array}{c}\text { Std. } \\
\text { Deviation }\end{array}$ & df & $\begin{array}{c}\mathrm{T} \\
\text { value }\end{array}$ & Sig. \\
\hline \multirow{2}{*}{1} & pre & 25 & 0.00 & 0.00 & \multirow{2}{*}{24} & \multirow{2}{*}{2.457} & \multirow{2}{*}{0.01} & \multirow{2}{*}{31} & Pre & 25 & 0.000 & 0.000 & \multirow{2}{*}{24} & \multirow{2}{*}{2.457} & \multirow{2}{*}{0.01} \\
\hline & post & 25 & 0.84 & 0.374 & & & & & Post & 25 & 0.840 & 0.374 & & & \\
\hline \multirow{2}{*}{2} & pre & 25 & 0.00 & 0.00 & \multirow{2}{*}{24} & \multirow{2}{*}{5.754} & \multirow{2}{*}{0.01} & \multirow{2}{*}{32} & Pre & 25 & 0.000 & 0.000 & \multirow{2}{*}{24} & \multirow{2}{*}{2.173} & \multirow{2}{*}{0.01} \\
\hline & post & 25 & 0.92 & 0.276 & & & & & Post & 25 & 0.720 & 0.458 & & & \\
\hline \multirow{2}{*}{3} & pre & 25 & 0.08 & 0.276 & \multirow{2}{*}{24} & \multirow{2}{*}{2.173} & \multirow{2}{*}{0.01} & \multirow{2}{*}{33} & Pre & 25 & 0.000 & 0.000 & \multirow{2}{*}{24} & \multirow{2}{*}{2.457} & \multirow{2}{*}{0.01} \\
\hline & post & 25 & 0.800 & 0.408 & & & & & Post & 25 & 0.840 & 0.374 & & & \\
\hline \multirow{2}{*}{4} & pre & 25 & 0.600 & 0.500 & \multirow{2}{*}{24} & \multirow{2}{*}{0.000} & & & Pre & 25 & 0.000 & 0.000 & & & \\
\hline & post & 25 & 0.96 & 0.201 & & & 0.00 & 34 & Post & 25 & 0.640 & 0.489 & 24 & $4.6 / 2$ & 0.01 \\
\hline 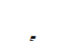 & pre & 25 & 0.56 & 0.506 & 2 & - & 正 & 2 & Pre & 25 & 0.000 & 0.000 & & & \\
\hline & post & 25 & 0.92 & 0.276 & & & & & Post & 25 & 0.720 & 0.458 & & 2.17 & \\
\hline 6 & pre & 25 & 0.00 & 0.00 & & & & 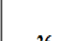 & Pre & 25 & 0.000 & 0.000 & & & \\
\hline & post & 25 & 0.88 & 0.331 & 27 & 1.020 & 0.01 & 50 & Post & 25 & 0.800 & 0.408 & 24 & 3.050 & 0.01 \\
\hline 7 & pre & 25 & 0.00 & 0.00 & $u$ & 167 & 005 & . & Pre & 25 & 0.000 & 0.800 & 4 & 3656 & 001 \\
\hline 1 & post & 25 & 0.84 & 0.374 & $2 f$ & 1.07 & $0.0 J$ & $\pi$ & Post & 25 & 0.000 & 0.408 & ${ }^{2+}$ & 5.000 & 0.01 \\
\hline 0 & pre & 25 & 0.120 & 0.841 & & 2177 & 004 & 90 & Pre & 25 & 0.000 & 0.000 & & 107 & 0.01 \\
\hline & post & 25 & 0.331 & 0.374 & & & & & Post & 25 & 0.72 & 0.458 & & & \\
\hline & pre & 25 & 0.20 & 0.920 & & & & & Pre & 25 & 0.000 & 0.000 & & & \\
\hline 3 & post & 25 & 0.408 & 0.276 & & 2.171 & 0.01 & 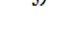 & Post & 25 & 0.880 & 0.331 & ${ }^{27}$ & 1.020 & \\
\hline (1) & pre & 25 & 0.00 & 0.000 & 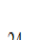 & 760 & 001 & (10 & Pre & 25 & 0.000 & 0.000 & & 2457 & م01 \\
\hline & post & 25 & 0.880 & 0.331 & & & & & Post & 25 & 0.840 & 0.374 & & & \\
\hline & pre & 25 & 0.00 & 0.000 & & & & & Pre & 25 & 0.000 & 0.000 & & & \\
\hline 11 & post & 25 & 0.800 & 0.408 & 27 & 0.020 & 0.01 & 71 & Post & 25 & 0.840 & 0.3749 & ${ }^{27}$ & $2 .+2 / 1$ & 0.01 \\
\hline & pre & 25 & 0.76 & 0.435 & & & & & Pre & 25 & 0.240 & 0.435 & & & \\
\hline 12 & post & 25 & 1.00 & 0.000 & 27 & 2.222 & 0.01 & 42 & Post & 25 & 0.720 & 0.458 & ${ }^{24}$ & 4.210 & 0.01 \\
\hline & pre & 25 & 0.000 & 0.800 & & & & & Pre & 25 & 0.00 & 0.00 & & & \\
\hline & post & 25 & 0.000 & 0.4082 & & & & 48 & Post & 25 & 0.720 & 0.458 & ${ }^{24}$ & $2.1 / 2$ & 0.01 \\
\hline & pre & 25 & 0.120 & 0.920 & & & & & Pre & 25 & 0.00 & 0.800 & & & \\
\hline 14 & post & 25 & 0.331 & 0.276 & 24 & 3.000 & 0.01 & 44 & Post & 25 & 0.00 & 0.408 & ${ }^{24}$ & 2.020 & 0.01 \\
\hline
\end{tabular}




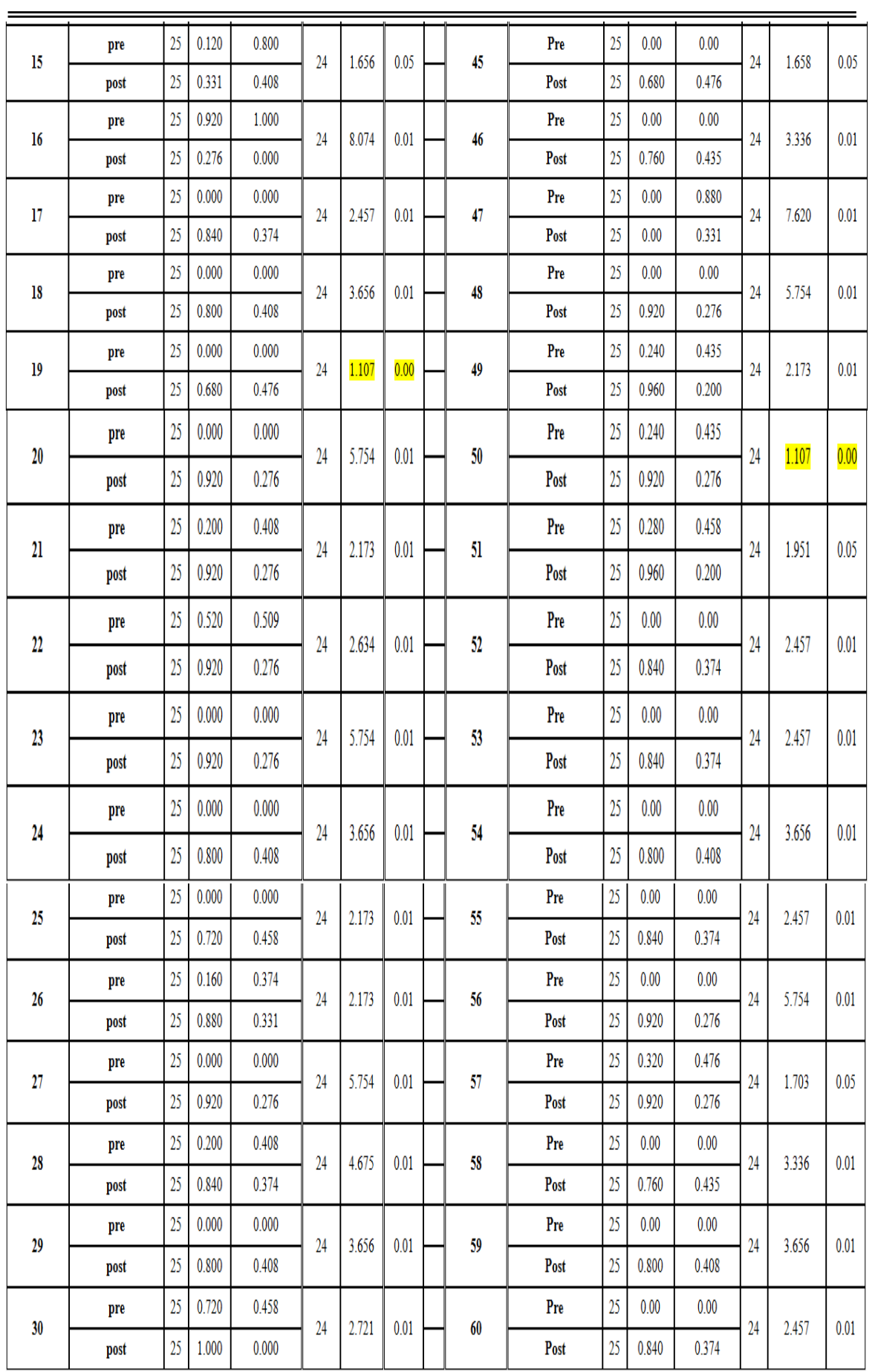

(t) Value is statistically significant at $(0.05)$ level, if it is or passed (1.65) value

(t) Value is statistically significant at (0.01) level, if it is or passed (2.33) valuel 
Table (7) Comparison of pre and post- test results for all test

\begin{tabular}{|c|c|c|c|c|c|c|c|c|c|}
\hline $\begin{array}{c}\text { Scientific } \\
\text { concept test } \\
\text { results for all } \\
\text { students }\end{array}$ & No. & $\begin{array}{c}\text { meas } \\
\text { ure }\end{array}$ & $\begin{array}{c}\text { Mea } \\
\mathrm{n}\end{array}$ & STDV. & df & t-value & Sign. & $\eta 2$ & $\begin{array}{c}\mathrm{d} \\
\text { (Eta) }\end{array}$ \\
\cline { 2 - 10 } & 25 & pre & 6.60 & 2.565801 & 24 & 2.34 & 0.01 & 0.18 & 0.955 \\
\hline
\end{tabular}

(d) Value is statistically significance as follow: (impact ratio is small if its $=/<0.2$, medium if it is $=/<0.5$, high if it is $=/>0.8$

The results of the study demonstrated that participant students in the gamification process had high levels of intrinsic motivation, and they achieved better results in general. The results showed the significant differences between the pre- and post-results at the level of $(0.01)$ in most of the test's items, and $(0.05)$ in $(7,15,45,51,57)$ questions, while there is no significance in the $(4,5,19,50)$ questions, and this may be due to the pre-knowledge of the students to the cell from the last grades. Moreover, the impact ratio was calculated and d was 0.95 , which is significant to the high impact of the module on students' acquiring to the scientific concepts.

The results of the study revealed that gamification had positive effects on active participation as well as on attendance in class and that the students found the gamification process more pleasing, motivating and interesting when compared to the traditional teaching process in the scientific concepts acquisition, Similarly Yapici\& Karakoym, (2017). Students gave a positive feedback on their flipped classroom, and the used strategies, which make the learning through gamification very interesting and matched their real life, which reflected on their learning, acquisition and retaining of the concepts and information, Furthermore, the gamification of content led to the large majority of students enjoying learning with the learning tool. Student feedback also highlights the potential for further developments, which would include the introduction of various difficulty levels to cater for diverse developmental stages of students. Other features of gamification, such as collecting points or high scores, could be implemented to spur on competitiveness among students and hence further their engagement with the learning tool and making their meaningful learning, and this matched with (Fleischmann\& Ariel,

2016). 
Second: Results of the administration of the CPS questionnaire, and checking the validity of the second hypothesis:

To verify the validity of the second hypothesis, means and standard of deviations of the post score for the experimental group, SPSS 9 package were applied using the one- pair t- test to illustrate the t- value and its significance, the next table illustrated the results:

Table (8) Comparison of pre and post- test results for CPS questionnaire parts

\begin{tabular}{|c|c|c|c|c|c|c|c|c|c|c|}
\hline Stage & $\begin{array}{l}\text { Questionnaire } \\
\text { parts }\end{array}$ & measurement & $\mathrm{N}$ & Mean & $\begin{array}{c}\text { Std. } \\
\text { Deviation }\end{array}$ & Df & $\begin{array}{c}\mathrm{T} \\
\text { value }\end{array}$ & Sig. & $\eta^{2}$ & $\underset{(\mathrm{Eta})}{\mathrm{d}}$ \\
\hline \multirow{4}{*}{$\begin{array}{l}\text { 1-Clarify } \\
\text { stage }\end{array}$} & \multirow{2}{*}{ First part } & pre & 25 & 9.16 & 1.598 & \multirow{2}{*}{24} & \multirow{2}{*}{2.36} & \multirow{2}{*}{0.01} & \multirow{2}{*}{0.18} & \multirow{2}{*}{0.96} \\
\hline & & post & 25 & 24.12 & 1.129 & & & & & \\
\hline & \multirow{2}{*}{ Second part } & pre & 25 & 1.32 & 1.1075 & \multirow{2}{*}{24} & \multirow{2}{*}{2.024} & \multirow{2}{*}{0.01} & \multirow{2}{*}{0.14} & \multirow{2}{*}{0.82} \\
\hline & & post & 25 & 4.72 & 1.173 & & & & & \\
\hline \multirow{4}{*}{$\begin{array}{l}\text { 2-Ideate } \\
\text { stage }\end{array}$} & \multirow{2}{*}{ First part } & pre & 25 & 3.60 & 0.866 & \multirow{2}{*}{24} & \multirow{2}{*}{6.640} & \multirow{2}{*}{0.01} & \multirow{2}{*}{0.64} & \multirow{2}{*}{2.71} \\
\hline & & post & 25 & 7.52 & 1.122 & & & & & \\
\hline & \multirow{2}{*}{ Second part } & pre & 25 & 3.56 & 1.502 & \multirow{2}{*}{24} & \multirow{2}{*}{1.375} & \multirow{2}{*}{0.00} & \multirow{2}{*}{0.07} & \multirow{2}{*}{0.56} \\
\hline & & post & 25 & 9.12 & 1.201 & & & & & \\
\hline \multirow{4}{*}{$\begin{array}{l}\text { 3-Develop } \\
\text { stage }\end{array}$} & \multirow{2}{*}{ First part } & pre & 25 & 7.64 & 13.36 & \multirow{2}{*}{24} & \multirow{2}{*}{8.877} & \multirow{2}{*}{0.01} & \multirow{2}{*}{0.76} & \multirow{2}{*}{3.63} \\
\hline & & post & 25 & 1.41 & 0.907 & & & & & \\
\hline & \multirow{2}{*}{ Second part } & pre & 25 & 4.40 & 2.140 & \multirow{2}{*}{24} & & & & \\
\hline & & post & 25 & 10.8 & 1.914 & & 3.345 & 0.01 & 0.24 & \\
\hline & First nart & pre & 25 & 11.68 & 2.230 & 24 & 1857 & 005 & 012 & 075 \\
\hline $\begin{array}{l}4- \\
\text { Imnlement }\end{array}$ & First part & post & 25 & 24.52 & 1.44 & 24 & 1.851 & 0.05 & 0.12 & 0.12 \\
\hline impleme & Second part & pre & 25 & 3.08 & 2.177 & 24 & 1268 & 000 & 006 & 0.51 \\
\hline & Secona part & post & 25 & 9.92 & 2.564 & 24 & 1.200 & 0.00 & 0.00 & 0.21 \\
\hline
\end{tabular}

(t) Value is statistically significant at (0.05) level, if it is or passed (1.65) value

(t) Value is statistically significant at (0.01) level, if it is or passed (2.33) value

(d) Value is statistically significance as follow: (impact ratio is small if its $=/<0.2$, medium if it is $=/<0.5$, high if it is $=/>0.8$

The results of the study demonstrated that participant students immersed in the gamification process had high levels of creativity after their orientation in the gamified cell module. By analyzing the last statistical table, there is a statistical significance between the post and pre measurement at the level of (0.01) in the four stages, and (0.05) in "the implement stage" at the first part. While there is no significance in "ideate and implement stages" at the second part, and this may be the difficulty of the second part problems, Moreover, because the creative problem solving is a skill needs 
more and more practices for a long time. the impact factor illustrated to each stage in the two parts in the last table. This matched with (Sanchez, 2011). This illustrated the efficacy of gamification in developing the creativity during solving the scientific problems through its challenges, which need organized mental procedures to overcome it and move from one stage or level to the other.

To check the effectiveness of the module, Corrected Ezzat's Ratio (CEG) was calculated to the SC test and CPS test through the next equation:

$$
\mathrm{CEG} \text { ratio }=\frac{M 2-M 1}{P-M 1}+\frac{M 2-M 1}{P}+\frac{M 2-M 1}{M 2}
$$

In which, M1= the mean of pre- measurement, M2= Mean of Premeasurement, $\mathrm{P}=$ total degree to test/ questionnaire. (The module is not effective if $\mathrm{CEG}=1<1.5$, has a medium effect when it is $1.5-1.8$, accepted and effective when it is $=/>1.8$ )

It was 2.65 to the scientific concepts test, and 1.92 to the CPS Questionnaire, which reflect the efficacy of the oriented module in increasing the scientific concepts of the cell content to the $2^{\text {nd }}$ prep students, and developing their creativity skills in problem- solving. Students reflected finally on their experiments in the module learning through gamification and the flipped classroom strategy, and they gave a positive responds and attitude ensuring that they really need fun and different strategies in their future learning.

\section{- Conclusion and Recommendations:}

In the light of the results of the current research, the researcher recommends the importance of preparing the science curricula based on gamifications, because it is one of the students real life tool, and due to its impact on developing their creativity. It is recommended to prepare and train the teachers to teach through gamification, flipped classroom and virtual learning environments, which enhance the meaningful learning and make the scientific concepts more durable in the students mind. Moreover, it is recommended to direct the attention of curriculum and program designers to place emphasis on Gamification and creative problem solving, and its strategies to develop the meaningful learning and creativity in science learning.

\section{- Suggestions for further research:}

In the light of the results of the current research, the researcher 
suggests the following researches:

The efficacy of gamification in developing the meaningful learning and critical thinking in science learning (physicschemistry- biology) for secondary grade students.

The efficacy of gamification in developing the creativity and motivation in science for the primary stage students.

The efficacy of a unit based on creative problem- solving model in developing the creative thinking skills for the secondary stage students.

The efficacy of creative problem solving model in developing the critical thinking and creativity in biology learning for secondary stage students.

The efficacy of creative problem solving model in developing the future thinking and decision making in biology learning for secondary stage students.

The efficacy of CPS model in developing the systematic thinking and knowledge management in biology learning for secondary stage students.

\section{References:}

- Al-abadi, Z. (2008). The Effect of an Educational Program based on problem solving model on developing creative thinking skills among gifted disabled students. PhD Dissertation, Arabic Amman Graduate Studies University, Amman: Jordan.

- Al-khatib, B. (2012). The Effect of Using Brainstorming Strategy in Developing Creative Problem Solving Skills among Female Students in Princess Alia University College. American International Journal of Contemporary Research, v. 2 (10) October, pp. 29-38.

- Al-lala, S. (2009). The effectiveness of a training program based on Trafnger model in developing creative problem solving among kindergarten children in Jordan, PhD Dissertation, Arabic Amman Graduate Studies University, Amman: Jordan.

- Al-Tarawneh, M. (2016). The Effectiveness of Educational Games on Scientific Concepts Acquisition in First Grade Students in Science. Journal of Education and Practice, v.7 (3), pp. 31-37, ISSN 2222-288X (Online).

- Annetta, L.; Cheng, M. \& Holmes, S. (2010). Assessing twenty-first century skills through a teacher created video game for high school 
biology teachers. Science and Technological Education, v. 28 (2), pp. $101-114$.

- Barko, T. \& Sadler, T. (2013). Learning outcomes associated with classroom implementation of a biotechnology-themed video game. The American Biology Teacher, v. 75 (1), pp. 29- 33.

- Becker, K. (2007). Digital game-based learning once removed: teaching teachers. British Journal of Educational Technology, v. 38 (3), pp. 478488.

- Bosche, W. (2010). Violent video games prime both aggressive and positive cognitions. Journal of Media Psychology: Theories, Methods, and Applications, v. 22 (4), pp. 139- 146.

- Buyukyıldırım, Ü. (2014). Oyunla"tırma (Gamification) Nedir? Accessed on: http: //www.bilim.org/oyunlastirma-gamification-nedir/ at: may 17, 2018.

- Christensen, C. \& Raynor, M. (2003). The Innovator's Solution: Creating and Sustaining Successful Growth.Harvard University Press: Cambridge, MA. ISBN: 978-1578518524.

- Clark, D.; Nelson, B.; Chang, H.; Martinez-Garza, M.; Slack, K. \& D’Angelo, C. (2011). Exploring Newtoinian mechanics in a conceptually integrated digital game: Comparison of learning and affective outcomes for students in Taiwan and the United States.Computers \& Education, v. 57 (3), pp. 2178-2195.

- Creative Education Foundation (2015). Creative Problem Solving Tools \& Techniques Resource Guide. Accessed online on: http://www.creativeeducationfoundation.org/wpcontent/uploads/2015/06/ToolsTechniques-Guide-FINAL-webwatermark.pdf, at: 14/7/2018.

- Deterding, S.; Dixon, D.; Khaled, R. \& Nacke, L. (2011). "From game design elements to gamefulness: defining gamification". In Proceedings of the 15th International Academic MindTrek Conference: Envisioning Future Media Environments, September 28-30, Tampere, Finland: ACM, pp. 9-15.

- Deterding, S.; Sicart, M.; Nacke, L.; O'Hara, K., \& Dixon, D. (2011). Gamification: Using Game-design Elements in Nongaming Contexts. CHI '11 Extended Abstracts on Human Factors in Computing Systems (CHI EA '11), ACM: New York- USA, pp. 2425-2428. Accessed on: http://doi.acm.org/10.1145/1979742.1979575- at: 7/7/2018.

- Elkind, D. (2008). The Power of Play: Learning What Comes Naturally. American Journal of Play, v. 1 (1). 
- Elnemr, M. (2015). The crisis of building science and math curricula, $17^{\text {th }}$ scientific conference for Scientific Education, Dar- Aldeyafa- Ainshams university, 10-11 August, pp. 11-18.

- Entertainment Software Association (2013). Essential facts about the computer and video game industry. Acessed on: http://www.theesa.com/facts/pdfs/esa_ef_2013.pdf.

At: $7 / 7 / 2018$.

- Farahani, M.; Hasan, M. \& Noroozi, N. (2014). The Study on Features of Informal Education in Postmodernism. Procedia - Social and Behavioral Sciences, v. 136, pp. 559-563.

- Ferdig, R. E. (Ed.) (2009). Handbook of research on effective electronic gaming in education. Hershey, PA: Information Science Reference, DOI: $10.4018 / 978-1-59904-808-6$.

- Ferguson, R. (2011). Meaningful learning and creativity in virtual worlds. Thinking skills and creativity, v.1 (1), 169-178.

- Fleischmann, F. \& Ariel, K. (2016). Gamification in Science Education: Gamifying Learning of Microscopic Processes in the Laboratory. CONTEMPORARY EDUCATIONAL TECHNOLOGY, v. 7 (2), pp. 138159.

- Fogleman, J.; McNeill, K. \& Krajcik, J. (2011). Examining the effect of teachers' adaptations of a middle school science inquiry-oriented curriculum unit on student learning. Journal of Research in Science Teaching, v. 48 (2), pp. 149- 169.

- Folta, E. (2010). Investigating the Impact on Student Learning and Outdoor Science Interest through Modular Serious Educational Games: A Design-Based Research. Doctor Dissertation, North Carolina State University, Raleigh, North Carolina.

- Gee. J. (2007). What video games have to teach is about learning and literacy (rev. and updated ed.). New York: Macmillan.

- Gentile, D.; Lynch, P.; Linder, J. \& Walsh, D. (2004). The effects of violent video game habits on adolescent hostility, aggressive behaviors, and school performance. Journal of Adolescence, v. 27 (1), pp. 5- 22.

- GLOVER, I. (2013). Play as you learn: gamification as a technique for motivating learners. In: HERRINGTON, Jan, COUROS, Alec and IRVINE, Valerie, (eds.) Proceedings of World Conference on Educational Multimedia, Hypermedia and Telecommunications 2013, Chesapeake, VA, AACE, pp. 1999- 2008. Accessed on:

http://shura.shu.ac.uk/information.html. At: 17/7/2018. 
- Hamari, J. (2013). "Transforming Homo Economicus into Homo Ludens: A Field Experiment on Gamification in a Utilitarian Peer-ToPeer Trading Service". Electronic Commerce Research and Applications, v. 12, n. 4, pp. 236-245.

- Hanus, M. (2015). Assessing the effects of gamification in the classroom: A longitudinal study on intrinsic motivation, social comparison, satisfaction, effort, and academic performance. Computers \& Education, v.80, January pp. 152-161.

- Hassard, J. \& Dias, M (2009). The Art of Teaching Science. Second Edition, Routledge Press, Taylor and Francis.

- Honey, M. \& Hilton, M. (Eds.). (2011). learning science through computer games and simulations, Washington, DC: National Academies Press.

- Hsu, C.; Tsai, C. \& Liang, J. (2011). Facilitating preschoolers' scientific knowledge construction via computer games regarding light and shadow: The effect of the prediction observation-explanation (POE) strategy. Journal of Science Education and Technology, v. 20 (5), pp. 482-493.

- Huotari, K. \& Hamari, J. (2012). "Defining gamification: a service marketing perspective". In Proceedings of the $16^{\text {th }}$ International Academic MindTrek Conference, October 3-5, Tampere, Finland, ACM, pp. 17-22.

- Inal, Y. \& Cagiltay, K. (2007). Flow experiences of children in an interactive social game environment. British Journal of Educational Technology, v. 38, pp. 455-464.

- Juul, J. (2003). The Game, the Player, and the World: Looking for a Heart of Gameness. Proceedings of Level Up: Digital Games Research Conference, 30-45. Accessed on: http://www.jesperjuul.net/text/gameplayerworld/ at: 7/7/2018

- Kapp, K. (2012). The gamification of learning and instruction: Gamebased methods and strategies for training and education. San Francisco: Wiley, ISBN: 978-1-118-09634-5.

- Ketelhut, D.; Nelson, B.; Clarke, J. \& Dede, C. (2010). A multi-user virtual environment for building and assessing higher order inquiry skills in science. British Journal of Educational Technology, v. 41 (1), pp. 5668.

- Khataybeh, A. (2011). Tadrees Aluloum liljamei-“Teaching science for all". Amman, Jordan: Dar Al-Massira Publishing Distribution \& Printing. 
- Kirriemuir, J., \& McFarlane, A. E. (2004). The Effectiveness of Educational Games on Scientific Concepts Acquisition in First Grade Students in Science. Games and learning. Bristol: Future lab. Retrieved on https://hal.archives-ouvertes.fr/hal-00190453/document.

- Klisch, Y.; Miller, L.; Wang, S. \& Epstein, J. (2012). The Impact of a Science Education Game on Students'Learning and Perception of Inhalants as Body Pollutants. Journal of Science Education \& Technology, v. 21, pp. 295-303.

- Klopfer, E.; Osterweil, S. \& Salen, K. (2009). Moving learning games forward. Cambridge, MA: The Education Arcade.

- Kuo, M. (2007). How does an online game based learning environment promote students' intrinsic motivation for learning natural science and how does it affect their learning outcomes?, Paper presented at the First IEEE International Workshop on Digital Game and Intelligent Toy Enhanced Learning, (DIGITEL'07), Jhongli, Taiwan.

- Liu, E. \& Chen, P. (2013). The Effect of Game-Based Learning on Students' Learning Performance in Science Learning- A Case of "Conveyance Go". Procedia- Social and Behavioral Sciences, v. 103, November, pp. 1044- 1051.

- Mahmoud, A. (2015). The efficacy of science teaching through SCAMPER strategy for information generation to develop the imaginative thinking and some habits of mind to the first prep. Stage' students. Journal of Science Education, v. 18 (4), July, pp. 1-50.

- McGonigal, J. (2011). Reality Is Broken: Why Games Make Us Better and How They Can Change the World. New York, NY: Penguin.

- Milne, C. \& Otieno, T. (2007). Understanding engagement: Science demonstrations and emotional energy.

- Michael D, Chen S (2006). Serious Games: Games That Educate, Train and Inform. Boston: Thomson Course Technology.

- Muntean, C. (2011). Raising engagement in e-learning through gamification. In Proceedings 6th International Conference on Virtual Learning, pp. 323-329.

- Murphy, G. (2002). The Big Book of Concepts, Cambridge, MA: MIT Press.

- Al-Nagdy, A., et al. (2003). New trends in Science Teaching in The light of Global Standards, Constructivism and Thinking Development. Egypt:

Dar Elfekr Alaraby. 
- Nelson, B. (2007). Exploring the use of individualized, reflective guidance in an educational multi-user virtual environment. Journal of Science Education and Technology, v. 16 (1), pp. 83- 97.

- Nicholson, S. (2012). Strategies for meaningful gamification: Concepts behind transformative play and participatory museums. Meaningful Play, Lansing, Michigan. Available online at

http://scottnicholson.com/pubs/meaningfulstrategies.pdf

- Pappas, Ch. (2016). 7 eLearning Gamification Tips To Enhance Problem Solving Skills. E-Learning Industry, November, 20. Accessed on:

https://elearningindustry.com/elearning-gamification-tips-enhanceproblem-solving-skills, at 20 may 2018.

- Puccio, G., Mance, M. \& Murdock, M. (2011). Creative leadership: Skills that drive change (Second Edition). London: Sage Publications.

- Rastegapour, H. \& Marashi, P. (2012). The effect of card games and computer games on learning of chemistry concepts. Procedia-Social and Behavioral Sciences, v. 31, pp. 597-601.

- Rovai, A.; Ponton, M.; Wighting, M. \& Baker, J. (2007). A Comparative Analysis of Student Motivation in Traditional Classroom and E-Learning Courses. International Journal on E-Learning, v. 6, n. 3, pp. 413-432. Accessed on: http://www.editlib.org/p/20022. At: 7/7/2018.

- Rubin-Vaughan, R.; Pepler, D.; Brown, S. \& Craig, W. (2011). Quest for the Golden Rule: An effective social skills promotion and bullying prevention program. Computers \& Education, v. 56, pp. 166-175.

- Ruzhitskaya, L.; Speck, A.; Ding, N.; Baldridge, S.; Witzig, S. \& Laffey, J. (2013). Going virtual or not: Development and testing of a 3 D virtual astronomy environment. Communicating Science: A National Conference on Science Education and Public Outreach, pp. 473, 255.

- Sadler, T. D., Romine, W., Stuart, P. E., \& Merle-Johnson, D. (2013). Game-based curricula in biology classes: Differential effects among varying academic levels. Journal of Research in Science Teaching, v. 50 (4), pp. 479- 499.

- Sadler, T.; Romine, W.; Menon, D.; Ferdig, R. \& Annetta, L. (2015). Learning Biology through Innovative Curricula: A Comparison of Game and Nongame-Based Approaches. Science Education, v. 99 (4), pp. 696720 .

- Salen, K. \& Zimmerman, E. (2004). Rules of play: Game design fundamentals. Cambridge, MA: MIT Press. Accessed on: 
https://gamifique.files.wordpress.com/2011/11/1-rules-of-play-gamedesign-fundamentals.pdf- 7/7/2018.

- Sanchez, J. (2011). Experiencing the Creative Problem Solving Thinking Skills Model in Virtual Worlds. Studies Graduate Student Master's Projects, $\quad$ paper $148 . \quad$ Accessed on: http://digitalcommons.buffalostate.edu/creativeprojects, at: $23 / 9 / 2018$.

- Shaffer, D. \& Serlin, R. (2004). What good are statistics that don't generalize? Educational Researcher, v. 33, pp. 14- 25.

- Shaffer, D. W. (2006). How Computer Games help Children learn. New York: Macmillan.

- Squire, K. \& Jan, M. (2007). Mad City Mystery: Developing scientific argumentation skills with a place-based augmented reality game on handheld computers. Journal of Science Education and Technology, v. 16 (1), pp. 5- 29.

- Squire, K. \& Jenkins, H. (2003). Harnessing the power of games in education. InSight, v. 3 (1), pp. 5- 33.

- Steinkuehler, C., \& Duncan, S. (2008). Scientific habits of mind in virtual worlds. Journal of Science Education and Technology, v. 17 (6), pp. 530- 543.

- Sung, y.; chang, K. \& Liu, T. (2016). The effects of integrating mobile devices with teaching and learning on students' learning performance. A meta-analysis and research synthesis, Computer\& education, v. 94, pp. 252-275.

- Al-Tarawneh, M. (2016). The Effectiveness of Educational Games on Scientific Concepts Acquisition in First Grade Students in Science. Journal of Education and Practice, v. 7 (3).

- Twining, P. (2010). Virtual worlds and education. Educational research, v. 52 (2), pp. 117-122. doi: 10.1080/00131881.2010.482730

- UNESCO (2010). Current Challenges in Basic Science Education, Accessed on

http://unesdoc.unesco.org/images/0019/001914/191425e.pdf $\quad$ at: 14/7/2018.

- Uribe, D. \& Cabra, J. (2010). Creative Problem Solving in Second Life: An action research study. Creativity and Innovation Management, v. 19 (2), pp. 167- 179.

- Yapici, U. \& Karakoym, F. (2017). Gamification in Biology Teaching: A 
Sample of Kahoot Application. Turkish Online Journal of Qualitative Inquiry (TOJQI), V. 8, 4, October, pp. 396-414, DOI: 10.17569/tojqi.335956.

- Zaytoon, A. (2003). Science Teaching Methods. Fourth edition, Oman: Dar Elshourouq.

- Zaytoon, M. (2013). Asaleeb Tadrees Al'uloum"-Methods of Teaching Science”. Amman, Jordan: Dar Al-Shorok Publishing Distribution \& Printing.

Zirbel, E. (2006). Teaching to Promote Deep Understanding and Instigate Conceptual Change. Bulletin of the American Astronomical Society, v. 38, pp. 1220-1244. 